\title{
Gastroprotective effect of Desmodium gangeticum roots on gastric ulcer mouse models
}

\section{Ayyavu Mahesh, ${ }^{* 1,2}$ Robert Jeyachandran, ${ }^{2}$ Dowlathabad Muralidhara Rao, ${ }^{3}$ Devarajan Thangadurai ${ }^{4}$}

\author{
${ }^{1}$ School of Biological Sciences, Madurai Kamaraj University, India. \\ ${ }^{2}$ Department of Plant Biology and Plant Biotechnology, St. Joseph's College, \\ India. \\ ${ }^{3}$ Department of Biotechnology, Sri Krishnadevaraya University, India. \\ ${ }^{4}$ Department of Botany, Karnatak University, Dharwad, India.
}

\begin{abstract}
In the present study, the ethanolic root extract of Desmodium gangeticum (L.) DC., Fabaceae, (EDG), have been studied in various acute and chronic ulcer mouse models. Oral administration of root extract, significantly decrease the ulcer index and lesion number in a dose dependent manner against ethanol induced acute gastric ulcer in mice. In gastric ulcerated animal that received high dose of $150 \mathrm{mg} / \mathrm{kg}$ EDG, the mucosa showed no ulceration with slight focal congestion and the glands appeared normal. Pylorus ligated mice, pretreated with EDG showed significant decrease in ulcerous activity under chronic condition. The highest dose $(150 \mathrm{mg} / \mathrm{kg})$ of the extract provoked a marked increase in protein and glutathione levels, when compare to control. Furthermore, gastric juice, free acidity and total acid output were inhibited in a dose-dependent manner at $p<0.05$ level. Our results indicate that the EDG possess gastroprotective activity and increasing regeneration of damaged gastric mucosa and thus safe for human use.
\end{abstract}

Revista Brasileira de Farmacognosia Brazilian Journal of Pharmacognosy 22(5): 1085-1091, Sep./Oct. 2012

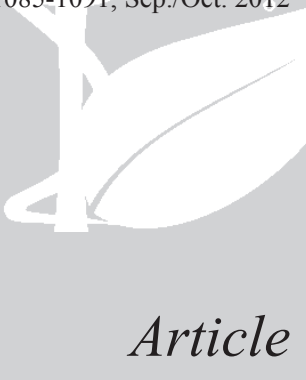

Received 25 Feb 2012

Accepted 1 May 2012

Available online 14 Jun 2012

Keywords: Desmodium gangeticum gastric ulcer gastroprotective activity Fabaceae Omeprazole

ISSN 0102-695X http://dx.doi.org/10.1590/S0102695X201200500008

\section{Introduction}

Gastric mucosal layers are continuously exposed to a wide variety of injurious agents originating either endogenously or exogenously. These include hydrochloric acid, pepsin, Helicobacter pylori, alcohol, and nonsteroidal anti-inflammatory drugs (NSAID). When these aggressive factors exceed the ability of the mucosa to resist, multiple pathologies such as gastritis, gastric ulcers, and even gastric cancer can develop (Choi et al., 2007). Gastric mucosal injury can be treated by allopathic drug therapy. However, there are many examples of recurrence. Therefore, a useful method for prevention of recurrence is needed. Food and other natural resources have been attracting attention as a preventive method, and many studies have been performed (Ch et al., 2004; Toma et al., 2005).

In recent years, many countries with important biodiversity resources are developing and using nontoxic preparations from medicinal plants for controlling various diseases, providing relief of symptoms comparable to that obtained from allopathic medicine (Bandyopadhyay et al., 2004). Among the conditions that can possibly profit from traditional medicine are gastrointestinal diseases, particularly gastric and duodenal ulcers. A number of plants have been proven to possess gastroprotective and ulcer-healing properties in gastric lesions induced by noxious agents
(Barbastefano et al., 2007; Vasconcelos et al., 2008).

Gastric ulcers are caused due to imbalances between offensive and defensive factors of the gastric mucosa. The antiulcerogenic activity of many plant products are reported due to an increase in mucosal defensive factors rather than decrease in the offensive factors (Goel et al., 1985). A number of antiulcer drugs like gastric antisecretory drugs- $\mathrm{H} 2$ receptor antagonists, antimuscarinic agents, proton pump inhibitors, mucosal protective agents carbenoxolone sodium, sucralfate and prostaglandin analogues are available which are shown to have side effects and limitations (Barrowman \& Pfeiffer, 1982).

Desmodium gangeticum (L.) DC., Fabaceae, is popularly known as Orila in Tamil language. It is a small shrub distributed in tropical region which has been used in Indian System of Medicine as a bitter tonic, febrifuge, digestive, anti-catarrhal, antiemetic, anti-inflammatory chest and various other inflammatory conditions due to vata disorders. The root is prescribed in combination with other drugs for the treatment of gastric ulcer, snakebite and scorpion sting (Varier, 1994; Yadava \& Tripathi, 1998). Root powder mixed with honey and applied frequently to treat mouth ulcer (Kosalge $\&$ Fursule, 2009). The aqueous extract of this species has been reported to show severe antiwrithing activity, moderate central nervous system (CNS) depressant activity and antileishmanial activity (Jabbar et al., 
2001). Anti-inflammatory and antioxidant activities of D. gangeticum flavonoid and alkaloid fractions have been reported in carrageenan-induced inflamed rats (Govindarajan et al., 2007). Nineteen compounds of various classes were isolated and identified from the Desmodium gangeticum whole plant. Aminoglucosyl glycerolipid was reported for the first time (Mishra et al., 2005). Three pterocarpenoids, gangetin, gangetinin and desmodin, are the major chemical constituents of the roots (Purushothaman et al., 1975). Recently a new pterocarpan, gangetial, has been isolated from the chloroform extract of the roots of D. gangeticum (Varaprasad et al., 2009). The aim of the present study was to evaluate the antiulcerogenic effect of different dose of ethanolic root extract of D. gangeticum on various experimental ulcer models.

\section{Materials and Methods}

\section{Animals}

Male albino mice (25-30 g) were used throughout the experiment. The animals were housed in polypropylene cages with sterile, inert husk materials as bedding. The experimental animals were maintained under controlled environment conditions of light and dark cycle (light $12 \mathrm{~h}$ : dark $12 \mathrm{~h}$, temperature $23 \pm 2{ }^{\circ} \mathrm{C}$ and relative humidity $55 \pm 10 \%$ ). They were allowed to acclimatize for one week and were provided a free access to standard pellet diet and water ad libitum. The experimental protocols were approved by the Animal Ethics Committee of Sri Krishnadevaraya University at Anantapur, India (Reg. No. 25/1/99/AWD).

\section{Preparation of plant extract}

Roots of Desmodium gangeticum (L.) DC., Fabaceae, were collected from Kolli hills in Tamil $\mathrm{Nadu}$, India. Identity of the plant was verified with the voucher specimen (RHT 19243) at Rapinat Herbarium, St. Joseph's College, Tiruchirappalli, India. The plant material was shade dried in air and then milled to a fine powder of $1 \mathrm{~mm}$ size. The dried and powdered plant material $(100 \mathrm{~g})$ was extracted with $600 \mathrm{~mL}$ of ethanol $(1: 6 \mathrm{w} / \mathrm{v})$ by using soxhlet apparatus for $8 \mathrm{~h}$ at a temperature not exceeding the boiling point of the solvent. The ethanol extract (EDG) was filtered using Whatman No. 1 filter paper, concentrated in vacuum at $40{ }^{\circ} \mathrm{C}$ using a rotary evaporator, transferred to glass vials and kept at $4{ }^{\circ} \mathrm{C}$ until use.

\section{Experimental protocol}

Ethanolic root extract of D. gangeticum (EDG) in doses of 50,100 and $150 \mathrm{mg} / \mathrm{kg}$ or $50 \mathrm{mg} / \mathrm{kg}$ of
Omeprazole were administrated orally once in daily for seven days for gastroprotective studies. The last doses of EDG or Omeprazole were given on the $7^{\text {th }}$ day, one hour prior to inducing gastric ulcer formation by ethanol and pylorus-ligated gastric ulcer models.

\section{Ethanol induced gastric ulcer in mice}

Male albino mice were fasted for $24 \mathrm{~h}$ prior to the experiments but water permitted ad libitum. The last doses of EDG and Omeprazole were given on the $7^{\text {th }}$ day; one hour prior to the oral administration of absolute ethanol $(1 \mathrm{~mL})$ to induce gastric ulcer (Pihan et al., 1987). One hour post administration of absolute ethanol, each animal was killed by cervical dislocation. The stomach was excised and injected with $3 \mathrm{ml}$ of $5 \%$ formalin solution. After $15 \mathrm{~min}$, the stomach was opened along the greater curvature, rinsed with tap water, and then inspected visually for destructive mucosal lesions. The extent of damage was expressed by the sum length of ( $\mathrm{mm})$ all lesions, lesion index, in the glandular area of stomach, and by the mean total number of lesions.

The inhibitory response of the treatment was calculated by:

$$
\% \text { Inhibition }=\frac{\text { Lesion index in control-Lesion index in test }}{\text { Lesion index in Control }} \times 100
$$

The percent inhibition of lesion number was also calculated similarly.

\section{Pylorus ligated gastric ulcer in mice}

Male albino mice were fasted for $24 \mathrm{~h}$, and the care was taken to avoid coprophagy. EDG, Omeprazole and vehicle were administrated to respective group $30 \mathrm{~min}$ prior to pyloric ligation. Pylorus-ligation was performed according to standard methods (Shay et al., 1945). Briefly, under light ether anesthesia, an abdomen midline incision was made extending $2 \mathrm{~cm}$ downwards from the xyphoid. The junction between the pylorus and the duodenum was picked up gently with a curved probe, while the stomach itself was not disturbed. A pyloric ligature was made using silk thread, care being taken to avoid damage of blood vessels or traction on the stomach. The abdominal wound was cleaned thoroughly with physiological saline. The anesthesia was discontinued and the animal usually recovered consciousness within less than $10 \mathrm{~min}$. Four hours later, the animals were submitted to euthanasia and the stomach was dissected out after suturing the lower oesophageal end. Gastric juice was collected in tubes for the estimation of biochemical parameters. 


\section{Determination of gastric juice and total acid output}

Gastric juice was collected $4 \mathrm{~h}$ after pylorus ligation, and centrifuged for $10 \mathrm{~min}$ at $3000 \mathrm{x} \mathrm{g}$. The volume of the supernatant was expressed as the amount of gastric juice $(\mathrm{mL})$. One $\mathrm{ml}$ of the supernatant liquid was pipette out and diluted to $10 \mathrm{~mL}$ distilled water. The solution was titrated against $0.01 \mathrm{~N} \mathrm{NaOH}$ using Topfer's reagent as indicator, to the endpoint when the solution turned to orange color. The volume of $\mathrm{NaOH}$ needed was taken as corresponding to the free acidity. Titration was further continued till the solution regained pink color. The volume of $\mathrm{NaOH}$ required was noted and was taken as corresponding to the total acidity (Shay et al., 1945). Acidity was expressed as:

$$
\text { Acidity }=\text { Volume of } \mathrm{NaOH} \times \text { Normality } \times 100 / 0.1=\mathrm{m} \mathrm{Eq} / \mathrm{L}
$$

\section{Estimation of glutathione and protein level}

GSH activity was quantified by the method of Jollow et al. (1974). From scrapings of glandular stomach mucosa of control and treated animals were assayed. Briefly, $1.0 \mathrm{~mL}$ of PMS (10\%) was precipitated with 1.0 $\mathrm{mL}$ of sulphosalicylic acid (4\%). The samples were kept at $4{ }^{\circ} \mathrm{C}$ for at least $1 \mathrm{~h}$ and then subjected to centrifugation at $1200 \mathrm{~g}$ for $15 \mathrm{~min}$ at $4{ }^{\circ} \mathrm{C}$. The assay mixture contained $0.1 \mathrm{~mL}$ filtered aliquot and $2.7 \mathrm{~mL}$ phosphate buffer $(0.1$ $\mathrm{M}, \mathrm{pH}$ 7.4) in a total volume of $3.0 \mathrm{~mL}$. The yellow color developed was measured immediately at $412 \mathrm{~nm}$ on a spectrophotometer. Protein concentration in all samples was determined by the method of Lowry et al (1951).

\section{Histopathological studies}

The gastric mucosal tissues from each group were fixed in $10 \%$ formalin for $24 \mathrm{~h}$. The fixative was removed by washing through running tap water overnight. After dehydration through graded series of alcohols, the tissues were cleaned in methyl benzoate, embedded in paraffin wax. Sections were cut into $5 \mu \mathrm{m}$ thickness and stained with haematoxylin and eosin. After dehydration and cleaning, the sections were mounted and observed under light microscope.

\section{Statistical analysis}

All the values are represented as mean \pm SED of six mice in each group. The statistical differences among different groups were analyzed using one-way analysis of variance (ANOVA) and Tukey's post-hoc test. The data were analyzed with SPSS version 13 software (SPSS Inc., Chicago, USA). The difference showing a level of $p<0.05$ was considered to be statistically significant.

\section{Results}

\section{Gastroprotective effect of EDG on ethanol induced} ulcer

The effect of EDG on ethanol induced gastric lesions and lesion index are shown in Table 1. The treatment of mice with absolute ethanol produced extensive gastric lesions in the glandular mucosa of the stomach in all the control mice. The lesion index and lesion number was $23.21 \pm 0.82$ and $13.83 \pm 0.45$ respectively in control mice $1 \mathrm{~h}$ after ethanol administration. Dose dependent gastroprotective effect against ethanol induced lesion index and ulcer number was observed. Pretreatment of mice with EDG for seven days at the doses of $50 \mathrm{mg} / \mathrm{kg}, 100 \mathrm{mg} / \mathrm{kg}$ and $150 \mathrm{mg} /$ $\mathrm{kg}$ significantly inhibited the formation of gastric lesions compared to control. Furthermore, treatment with omeprazole exhibited inhibition in lesion index and lesion numbers, whereas the higher dose of EDG $(150 \mathrm{mg} / \mathrm{kg})$ treated mice showed 85.04 and $73.39 \%$ inhibition respectively. The potency of higher dose of EDG was comparable with omeprazole.

Table 1. Effect of Desmodium gangeticum ethanolic root extracts on ethanol induced gastric lesion in mice.

\begin{tabular}{|c|c|c|c|c|c|}
\hline Treatment & $\begin{array}{c}\text { Dose } \\
(\mathrm{mg} / \mathrm{kg})\end{array}$ & $\begin{array}{l}\text { Lesion } \\
\text { Index } \\
(\mathrm{mm})\end{array}$ & $\%$ ILI & $\begin{array}{l}\text { Lesion } \\
\text { Number }\end{array}$ & $\%$ ILN \\
\hline Control & - & $23.21 \pm 0.82$ & - & $13.83 \pm 0.45$ & - \\
\hline D. gangeticum & 50 & $15.68 \pm 0.12$ & 32.44 & $10.05 \pm 0.34$ & 27.33 \\
\hline D. gangeticum & 100 & $9.78 \pm 0.35^{*}$ & 57.86 & $7.30 \pm 0.36^{*}$ & 47.21 \\
\hline D. gangeticum & 150 & $3.47 \pm 0.47 *$ & 85.04 & $3.68 \pm 0.30^{*}$ & 73.39 \\
\hline Omeprazole & 50 & $3.40 \pm 0.33^{*}$ & 85.35 & $3.52 \pm 0.27 *$ & 74.54 \\
\hline
\end{tabular}

Effect of EDG on gastric juice secretion of pylorusligated mice

Table 2 shows the protective effect of EDG on gastric juice secretion of pylorus-ligated mice. Pretreatment of EDG for seven days exhibited suppression of gastric juice secretion, total acid output and free acidity in a dose-dependent manner. Notably, the effect was remarkable for the dose of $150 \mathrm{mg} /$ $\mathrm{kg}$. In mice, pylorus ligation $4 \mathrm{~h}$ later, resulted in the accumulation of gastric secretion in the mice treated with 100 and $150 \mathrm{mg} / \mathrm{kg}$ of EDG significantly $(p<0.05)$ reduced. A significantly decreased $(p<0.05)$ of total acid output and free acidity was also observed in the mice treated with $100 \mathrm{mg} / \mathrm{kg}$ and $150 \mathrm{mg} / \mathrm{kg}$ (Table 2). 
Table 2. Effect of Desmodium gangeticum ethanolic root extracts on gastric juice secretion, total acid output and free acidity in pylorus-ligated mice.

\begin{tabular}{lcccc}
\hline Treatment & $\begin{array}{c}\text { Dose } \\
(\mathrm{mg} / \mathrm{kg})\end{array}$ & $\begin{array}{c}\text { Volume of } \\
\text { gastric juice } \\
\text { secretion } \\
(\mathrm{mL})\end{array}$ & $\begin{array}{c}\text { Total acid } \\
\text { output } \\
(\mu \mathrm{Eq} / \mathrm{h})\end{array}$ & $\begin{array}{c}\text { Free acidity } \\
(\mu \mathrm{Eq} / \mathrm{h})\end{array}$ \\
\hline Control & - & $3.66 \pm 0.17$ & $58.38 \pm 0.84$ & $26.72 \pm 0.45$ \\
D. gangeticum & 50 & $3.39 \pm 0.23$ & $52.36 \pm 0.79$ & $20.84 \pm 0.29$ \\
D. gangeticum & 100 & $2.38 \pm 0.17^{*}$ & $35.85 \pm 0.93^{*}$ & $14.20 \pm 0.31^{*}$ \\
D. gangeticum & 150 & $1.21 \pm 0.31^{*}$ & $19.61 \pm 0.31^{*}$ & $11.28 \pm 0.39^{*}$ \\
Omeprazole & 50 & $1.05 \pm 0.22^{*}$ & $18.55 \pm 0.65^{*}$ & $9.67 \pm 0.22^{*}$ \\
\hline
\end{tabular}

Gastroprotective effect of EDG on glutathione activity and protein level

Pylorus-ligated mice significantly decreased the glutathione and protein level in the gastric mucosa (Table 3). Pretreatment of mice with EDG at the doses of $100 \mathrm{mg} / \mathrm{kg}$ and $150 \mathrm{mg} / \mathrm{kg}$ significantly $(p<0.05)$ increased the glutathione and protein level of gastric mucosa as compared to control. The mice treated with $150 \mathrm{mg} / \mathrm{kg}$ of EDG significantly $(p<0.05)$ enhanced the glutathione levels compared to standard drug, Omeprazole (Table 3).

Each value represent Mean $\pm \mathrm{SEM}, \mathrm{n}=5,{ }^{*} p<0.05$ compared with control.
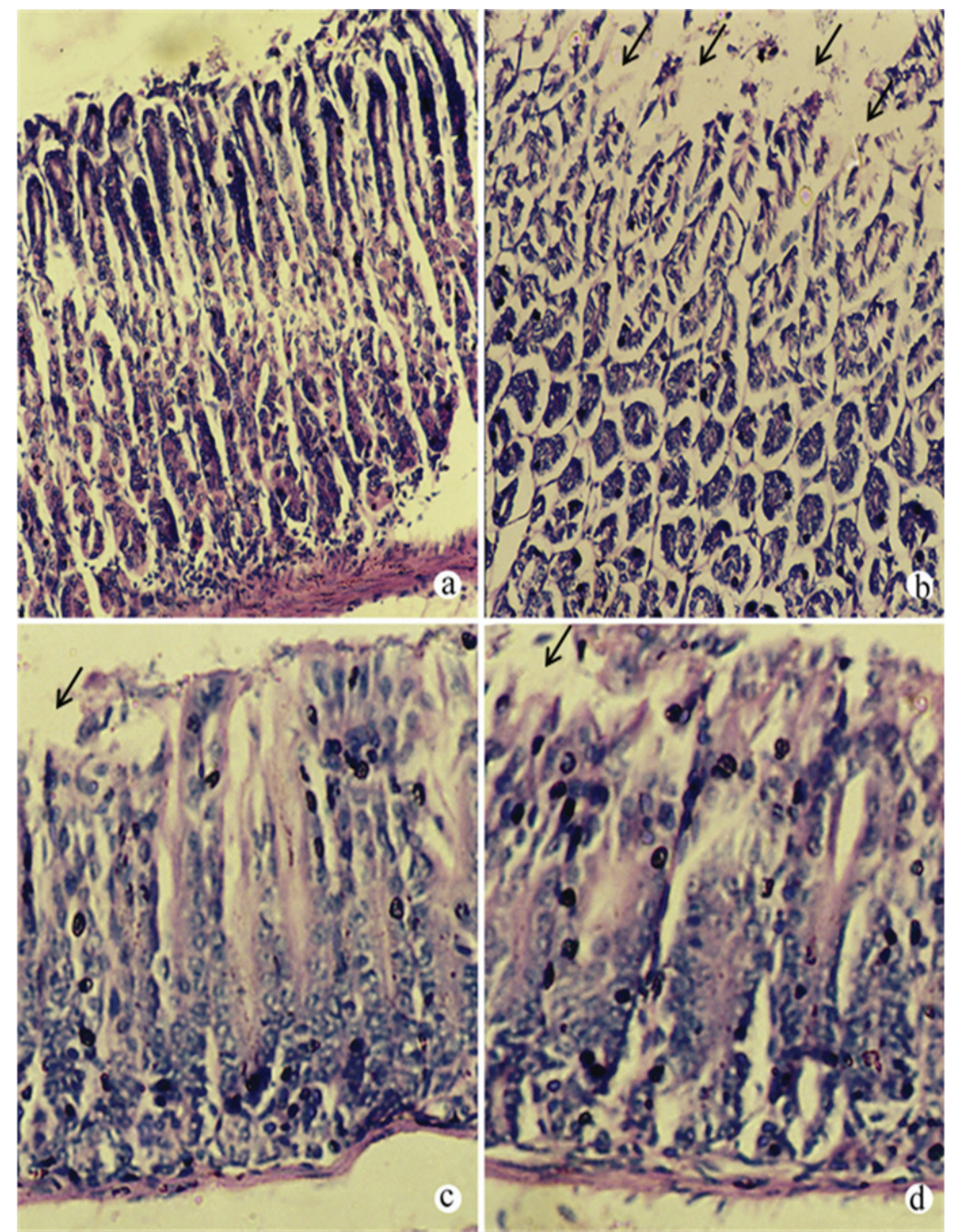

Figure 1. Histological examinations of gastric mucosal tissue sections of control and experimental mice (a) Normal histological appearance of the gastric mucosa of intact control mice (b) Histological appearance of the gastric mucosa of an absolute ethanoltreated animal. Disruption and exfoliation of the superficial gastric epithelium (c) The gastric mucosa of mice receiving pretreatment of EDG and absolute ethanol (d) The gastric mucosa of mice receiving Omeprazole and absolute ethanol. 
Table 3. Effect of Desmodium gangeticum ethanolic root extracts on total protein and glutathione in pylorus-ligated mice.

\begin{tabular}{lccc}
\hline \multicolumn{1}{c}{ Treatment } & Dose $(\mathrm{mg} / \mathrm{kg})$ & $\begin{array}{c}\text { Glutathione } \\
(\mathrm{mg} / \mathrm{g})\end{array}$ & $\begin{array}{c}\text { Total protein } \\
(\mathrm{mg} / 100 \mathrm{~g})\end{array}$ \\
\hline Control & - & $0.54 \pm 0.07$ & $521.05 \pm 2.38$ \\
D. gangeticum & 50 & $0.65 \pm 0.09$ & $564.33 \pm 1.9$ \\
D. gangeticum & 100 & $0.75 \pm 0.02^{*}$ & $607.32 \pm 2.09^{*}$ \\
D. gangeticum & 150 & $0.92 \pm 0.04^{*}$ & $708.65 \pm 1.69^{*}$ \\
Omeprazole & 50 & $0.93 \pm 0.02^{*}$ & $734.45 \pm 2.63^{*}$ \\
\hline
\end{tabular}

Each value represent Mean $\pm \mathrm{SEM}, \mathrm{n}=5,{ }^{*} p<0.05$ compared with control.

\section{Histopathological studies}

In microscopic examination of control mice treated with saline, gastric mucosa stained by hematoxylin eosin showed normal mucosal glands with intact epithelial surfaces (Figure 1a). Administration of absolute ethanol produced severe hemorrhagic necrotic lesions in the gastric mucosa manifested as: disruption and exfoliation of the superficial gastric epithelium; disappearance of the mucous cells from the upper portion of fundic glands; vacuolization, necrosis and cell damage extending into the gastric glands in some areas; and extensive hemorrhage in the mucosa (Figure 1b). Pretreatment with EDG orally showed a protective effect against ethanol-induced gastric ulcer. In gastric animal receiving high dose $(150 \mathrm{mg} / \mathrm{kg})$ of EDG the mucosa showed no ulceration, but focal slight congestion and the glands appeared normal. There is mild cellular infiltration in the submucosa (Figure 1c).

\section{Discussion}

The present study describes the effect of ethanolic root extract of Desmodium gangeticum (L.) DC., Fabaceae, on gastric ulcer mouse models. Several studies have proved that D. gangeticum possessed antioxidant activity (Kurian et al., 2010; Kurian et al., 2009; Kurian \& Paddikkala, 2009; Govindarajan et al., 2007; Govindarajan et al., 2003). In another study pretreatment of rats with aqueous extract of $D$. gangeticum orally for thirty days showed significantly improved preservation of antioxidant enzymes (SOD; CAT; GPX and glutathione reductase, GR) and subsequent reduction in LPO (Kurian \& Paddikkala, 2009). Recently, many authors have claimed that pharmacological activity of D. gangeticum such as, the aqueous extract of root and aerial parts of D. gangeticum was also found to have significant anti-inflammatory and analgesic activities in experimental animals (Rathi et al., 2004). The chloroform extract of D. gangeticum roots exhibited the hepatoprotective activity against carbon tetrachloride induced liver damage in rats (Prasad et al., 2005). Kurian et al. (2005), suggested free radical scavenging potential of aqueous extract of $D$. gangeticum root in isoproterenol induced myocardial infarction rats.

The ethanolic root extract of D. gangeticum produced a dose dependent decrease in the volume, free acidity and acid output of gastric secretions in mice (Table 2 ). The increase in gastric acidity is considered as an important contributing factor in the pathogenesis of gastric and duodenal ulcers and is often termed as the 'aggressive factor' (Goa et al., 1987). Ethanol serves as a most common ulcerogenic agent and when given intragastrically to mice, it produces severe gastric hemorrhagic erosions (Shetty et al., 2000). The genesis of ethanol-induced gastric lesions is multi-factorial with the depletion of gastric wall mucus content as one of the involved factors (Al-Harbi et al., 1997) and this damage induced by ethanol may be due to mucosal leukotriene release. Mucosal blood flow has also been attributed as an important factor in the damage caused by alcohol and is modulated by prostaglandin. It has been reported that submucosal venular constriction by ethanol and eventual injury is caused due to perturbations of superficial mucosal cells (Vanisree et al., 1996).

The antiulcer activity of EDG may be attributed for some extent to its ability to inhibit gastric acid secretions and to preserve mucosal integrity. Our results revealed that EDG significantly protected gastric mucosa against the depletion of gastric wall mucus (Table 2). Dharmani et al. (2005) has been reported the anti-ulcerogenic property of ethanolic extract of $D$. gangeticum whole plant against gastric ulcer models in Sprague-Dawley rats, and guinea pigs. The mucus gel adhering to the gastric mucosal surface protects the underlying epithelium against acid (Slomiany et al., 1985), and necrotizing agents such as ethanol. It plays a more important role in the defense of the gastric mucosa against chemical or mechanical aggressions than the soluble mucus found in the lumen of the stomach (Allen et al., 1986). The gastric mucus coat is thought to be important in facilitating the repair of the damaged gastric epithelium (Wallace \& Whittle, 1986). It seemed likely that the cytoprotective activity of EDG could result, at least in part, from its interaction with the adhering gastric mucus layer. These results further suggested that cytoprotection is the major mechanism responsible for the anti-ulcer activity of EDG as it produces the significant anti-ulcer effects. Hence, the result has also agreed with previous reports of the ethanolic whole plant extract of the same species (Dharmani et al., 2005). On the other hand, Omeprazole the standard drug produces anti-ulcer effects by inhibiting gastric secretion, total acid output and reducing the free acidity. Recently, many authors have been used Omeprazole as a standard drug for drug screening studies (Firdous et al., 2012; Takawale et al., 2011). 
The regulation of gastric acid secretion is complex and maintained by endogenous gastrin, histamine, somatostatin and cholinergic mechanisms. For acid secretion the expulsion of $\mathrm{H}^{+}$across the apical membrane is coupled with the movement of $\mathrm{K}^{+}$into the cell (Hanson \& Hatt, 1989). Phospholipase A2 inhibitors are known to modulate proton conductance across cell membranes (Evans \& Surprenant, 1993). Activation of parietal cell resulted in active transport of $\mathrm{H}^{+}$and associated with increased substrate oxidation may trigger the generation of $\mathrm{H}_{2} \mathrm{O}_{2}$ like other cells. Increased intracellular $\mathrm{H}_{2} \mathrm{O}_{2}$ is cytotoxic and is thus rapidly scavenged by the different types of peroxidases by utilizing glutathione, resulted in the depletion of glutathione (Das et al., 1995). The decreased gastric glutathione level by ethanol is in agreement with other reports, which have demonstrated the important role of glutathione in gastric mucosal damage (Jimmy et al., 1997).

As glutathione being a cofactor in $\mathrm{PG}$ synthesis, it will help the conversion of $\mathrm{PGG}_{2}$ to $\mathrm{PGH}_{2}$ and subsequently $\mathrm{PGE}_{2}$ (Shen, 1979). This will lead to the formation of different protective prostaglandins. Prostaglandins have an established role in the protection of gastric mucosa against different types of gastric lesions. Of particular interest is the fact that the antisecretory prostaglandins can protect the mucosa at non-antisecretory dosage (Alarcon et al., 1993). Hence, the protective effect of EDG against ethanol induced ulcer may be due to increase in glutathione levels. The histopathological studies also confirm the beneficial effects of EDG against ethanol induced gastric ulcer. In conclusion, the results indicate that the EDG possesses gastroprotective activity and wide safety margin. And, these findings may support the traditional uses of $D$. gangeticum extract to manage peptic ulcer. Further studies are needed to isolate and purify the active principle(s) involved in the antiulcer activity of this plant.

\section{Acknowledgments}

This article is dedicated to the memory of Mr. A. Ayyavu, to whom we are also thankful for his encouragements. Authors would like to thank Dr. S. Soosairaj and Dr. G. Mathan for helpful discussion and critical reading of the manuscript.

\section{References}

Alarcon C, Lopez A, Motilva V 1993. Gastroprotection and prostaglandin E2 generation in rats by flavonoids of Dittrichia viscose. Planta Med 59: 497-501.

Al-Harbi MM, Quershi S, Raza M, Ahmed MM, Afzal M, Shah AH 1997. Gastric antiulcer and cytoprotective effect of Commiphora molmol in rats. J Ethnopharmacol 55:
141-150.

Allen A, Hutton DA, Leonard AJ, Pearson JP, Sellers LA 1986. The role of mucus in the protection of the gastroduodenal mucosa. Scand J Gastroentero 125: 71-78.

Bandyopadhyay U, Biswas K, Sengupta A, Moitra P, Dutta P, Sarkar D, Debnath P, Ganguly CK, Banerjee RK 2004. Clinical studies on the effect of Neem (Azadirachta indica) bark extract on gastric secretion and gastro duodenal ulcer. Life Sci 75: 2867-2878.

Barbastefano V, Cola M, Luiz-Ferreira A, Farias-Silva E, Hiruma-Lima CA, Rinaldo D, Vilegas W, Souza-Brito ARM 2007. Vernonia polyanthes as a new source of antiulcer drugs. Fitoterapia 78: 545-551.

Barrowman JA, Pfeiffer CJ 1982. Carbenoxolone: A critical analysis of its clinical value in peptic ulcer. In: Drugs and Peptic Ulcer. Pfeiffer CJ (ed.), CRL Press, Boca Raton, p. 123-132.

Ch VR, Oja SK, Radhakrishnan K, Govindarajan R, Rastogi S, Mehrotra S, Pushpangadan P 2004. Antiulcer activity of Utleria salicifolia rhizome extract. $J$ Ethnopharmacol 91: 243-249.

Choi SM, Shin JH, Kang KK, Ahn BO, Yoo M 2007. Gastroprotective effects of DA-6034, a new flavonoid derivative, in various gastric mucosal damage models. Digest Dis Sci 52: 3075-3080.

Das D, De PK, Banerjee RK 1995. Thiocyanate, a plausible physiological electron donor of gastric peroxide. Biochem J 305: 59-64.

Dharmani P, Mishra PK, Maurya R, Chauhan VS, Palit G 2005. Desmodium gangeticum: a potent anti-ulcer agent. Indian J Exp Biol 43: 517-521.

Evans RJ, Surprenant A 1993. Effects of phospholipase A2 inhibitors on coupling of alpha 2-adrenoceptors to inwardly rectifying potassium currents in guinea-pig submucosal neurons. Brit J Pharmacol 110: 591-596.

Firdous SM, Neraja K, Debnath R, Dipak S, Sravanthi K 2012. Evaluation of antiulcer activity of ethanolic extract of Sechium edule fruits in experimental rats. Int J Pharm Pharmaceut Sci 4: 374-377.

Goa KL, Monk JP, Enprostil A 1987. Preliminary review of its pharmacodynamic and pharmacokinetic properties, and therapeutic efficacy in the treatment of peptic ulcer disease. Drugs 34: 539-559.

Goel RK, Chakrabarthy A, Sanyal AK 1985. The effect of biological variables on the antiulcerogenic effect of vegetable plantain banana. Planta Med 2: 85-88.

Govindarajan R, Rastogi S, Vijayakumar M, Shirwaikar A, Rawat AKS, Mehrotra S, Pushpangadan P 2003. Studies on the antioxidant activities of Desmodium gangeticum. Biol Pharm Bull 26: 1424-1427.

Govindarajan RM, Vijayakumar ChV, Rao A, Shirwaikar S, Rawatkumar AK, Pushpangadan P 2007. Antiinflammatory and antioxidant activities of Desmodium gangeticum fractions in carrageenaninduced inflamed rats. Phytother Res 21: 
975-979.

Hanson PJ, Hatt JF 1989. Intracellular signalling and regulation of gastric acid secretion. QJ Exp Physiol 74: 607-634.

Jabbar S, Khan MT, Choudhuri MS 2001. The effects of aqueous extracts of Desmodium gangeticum DC. (Leguminosae) on the central nervous system. Pharmazie 56: 506-508.

Jimmy YC, Chow LM, Min Zhu, Chi H 1997. The potentiating actions of cigarette smoking on ethanol induced gastric mucosal damage in rats. Gastroenterology 113: 1188-1197.

Jollow D, Mitchell L, Zampaglione N, Gillete J 1974. Bromobenze induced liver necrosis: Protective role of glutathione and evidence for 3,4-bromobenzenoxide as the hepatotoxic intermediate. Pharmacology 11: 151-169.

Kosalge SB, Fursule RA 2009. Investigation of ethnomedicinal claims of some plants used by tribals of Satpuda Hills in India. Journal of Ethnopharmacology 121: 456-461.

Kurian GA Paddikkala J 2009. Administration of aqueous extract of Desmodium gangeticum (L) root protects rat heart against ischemic reperfusion injury induced oxidative stress. Indian J Exp Biol 47: 129-135.

Kurian GA, Philip S, Varghese T 2005. Effect of aqueous extract of the Desmodium gangeticum DC root in the severity of myocardial infarction, J Ethnopharmacol 97: 457.

Kurian GA, Rajamani T, Ramanarayanan P, Paddikkala J 2009. A comparative study on in vitro and in vivo antioxidant activities of aqueous extract of Desmodium gangeticum (Leguminosae) root. Int J Green Pharm 3: 324-331.

Kurian GA, Suryanarayanan S, Raman A, Padikkala J 2010. Antioxidant effects of ethyl acetate extract of Desmodium gangeticum root on myocardial ischemia reperfusion injury in rat hearts. Chinese Med 5: 3 .

Lowry OM, Rosebrough NJ, Farr AL, Randall RJL 1951. Protein measurement with folin phenol reagent. J Biol Chem 193: 265-275.

Mishra PK, Singh N, Ahmad G, Dube A, Maurya R 2005. Glycolipids and other constituents from Desmodium gangeticum with antileishmanial and immunomodulatory activities. Bioorg Med Chem Lett 15: 4543-4546.

Pihan G, Regillo C, Szabo S 1987. Free radical and lipid peroxidation in ethanol or aspirin-induced gastric mucosal injury. Digest Dis Sci 32: 1395-1401.

PrasadMVV,BalakrishnaK, CareyMW 2005. Hepatoprotective activity of roots of Desmodium gangeticum (Linn.) DC. Asian J Chem 17: 2847-2849.

Purushothaman KK, Chandrasekharan S, Balakrishna K, Connolly JD 1975. Gangetinin and desmodin, two minor pterocarpanoids of Desmodium gangeticum. Phytochemistry 14: 1129-1130.

Rathi A, Rao CV, Ravishankar B, De S, Mehrotra S 2004. Anti-inflammatory and anti-nociceptive activity of the water decoction Desmodium gangeticum. $J$ Ethnopharmacol 95: 259-263.

Shay H, Komarov SA, Fels SS, Meranze D, Gruenstein M, Siplet H 1945. A simple method for the uniform production of gastric ulceration. Gastroenterology 5: 43-61.

Shen TY 1979. Prostaglandin synthetase inhibitions. In: Handbook of Experimental pharmacology. Vane JR \& Ferreira SH (eds.), Springer-Verlag, Berlin, p. 305347.

Shetty R, Kumar KV, Naidu MUR, Ratnakar KS 2000. Effect of Gingko biloba extract on ethanol-induced gastric mucosal lesions in rats. Indian J Pharmacol 32: 313-317.

Slomiany BL, Piasek A, Sarosiek J, Slomiany A 1985. The role of surface and intracellular mucus in gastric mucosal protection against hydrogen ion compositional differences. Scand J Gastroentero 20: 1191-1196.

Takawale H, Mute V, Awari D, Hukkeri VI, Mehta P, Vawhal P 2011. Screening of Antiulcer Activity of Caesalpinia pulcherrima L. Bark. Against Aspirin Induced Ulcer in Rats. World J Med Sci 6: 168-172.

Toma W, Hiruma-Lima CA, Guerrero RO, Brito AR 2005. Preliminary studies of Mammea americana L. (Guttiferae) bark/ latex extract point to an effective antiulcer. Phytomedicine 12: 345-350.

VanisreeAJ, Mitra K, Shyamala Devi CS 1996. Antiulcerogenic effect of UL-409 against experimentally induced gastric ulcer in rats. Indian J Pharmacol 28: 265268.

Varaprasad MV, Balakrishna K, Sukumar E, Patra A 2009. Gangetial, a new pterocarpan from the roots of Desmodium gangeticum. Journal of the Indian Chemical Society 86: 654-656.

Varier PS 1994. Indian medicinal plants, a compendium of 500 species. Orient Longman Ltd, Madras.

Vasconcelos PCP, Kushima H, Andreo M, Hiruma-Lima CA, Vilegas W, Takahira RK, Pellizzon CH 2008. Studies of gastric mucosa regeneration and safety promoted by Mouriri pusa treatment in acetic acid ulcer model. J Ethnopharmacol 115: 293-301.

Wallace JL, Whittle BJ 1986. Role of mucus in the repair of gastric epithelial damage in the rat. Inhibition of epithelial recovery by mucolytic agents. Gastroenterology 91: 603-611.

Yadava RN, Tripathi P 1998. A novel flavone glycoside from the stem of Desmodium gangeticum. Fitoterapia 69: 443-444.

\section{*Correspondence}

Ayyavu Mahesh

School of Biological Sciences, Madurai Kamaraj University Madurai 625 021, Tamilnadu, India.

mahesh.a@dbtiplsmku.org

Tel.: +919843874873 